\title{
Pengaruh Kegiatan Keagamaan terhadap Kualitas Pendidikan
}

\author{
Icep Irham Fauzan Syukri \\ Institut Agama Islam Darussalam (IAID) Ciamis, Jawa Barat. \\ Email: icep_irs@gmail.com
}

Soni Samsu Rizal

Prodi Pendidikan Islam Anak Usia Dini, Fak. Tarbiyah, Institut Agama Islam Darussalam (IAID)

Ciamis, Jawa Barat.

Email: soni.samsurizal@yahoo.co.id

\section{Djaswidi Al Hamdani}

Program Pascasarjana, Institut Agama Islam Darussalam (IAID) Ciamis, Jawa Barat.

Email: m.djaswidi@gmail.com

Received: November 18, 2018 | Accepted: March 15, 2019

\begin{abstract}
This study aims to determine the effect of religious activities on the quality of education in Madrasah Tsanawiyah Negeri 4 Pangandaran. This study uses correlational quantitative descriptive methods. Data collection using observation techniques, questionnaires, and documentation. The steps of analyzing research data include: data editing, scoring, prerequisite tests, and hypothesis testing. The results showed that: First, Religious Activities in Madrasah Tsanawiyah Negeri 4 Pangandaran included in the sufficient category. Second, the Quality of Education in Madrasah Tsanawiyah Negeri 4 Pangandaran is included in the sufficient category. Third, there is a significant influence between religious activities on the quality of education in Madrasah Tsanawiyah Negeri 4 Pangandaran. This is consistent with the results of SPSS 20 analysis that the sig value of $0,000<0.05$ shows that there is an influence of religious activities on the quality of education.
\end{abstract}

\begin{abstract}
Abstrak
Penelitian ini bertujuan untuk mengetahui pengaruh kegiatan keagamaan terhadap kualitas pendidikan di Madrasah Tsanawiyah Negeri 4 Pangandaran. Penelitian ini menggunakan metode deskriptik kuantitatif korelasional. Pengumpulan data menggunakan teknik observasi, angket, dan dokumentasi. Langkah-langkah analisis data hasil penelitian meliputi: editing data, skoring, uji persyaratan, dan uji hipotesis. Hasil penelitian menunjukan bahwa: Pertama, Kegiatan Keagamaan di Madrasah Tsanawiyah Negeri 4 Pangandaran termasuk kategori cukup. Kedua, Kualitas Pendidikan di Madrasah Tsanawiyah Negeri 4 Pangandaran termasuk kategori cukup. Ketiga, Terdapat pengaruh yang signifikan antara kegiatan keagamaan terhadap kualitas pendidikan di Madrasah Tsanawiyah Negeri 4 Pangandaran. Hal ini sesuai dengan
\end{abstract}


hasil analisis SPSS 20, bahwa nilai sig sebesar 0,000 $<0,05$ hal ini menunjukkan bahwa terdapat pengaruh kegiatan keagamaan terhadap kualitas pendidikan.

\section{Keywords}

Islamic education, religious activities, quality of education

\section{Pendahuluan}

Pendidikan pada saat ini dihadapkan pada tuntutan tujuan yang semakin canggih, semakin meningkat baik ragam, lebih-lebih kualitasnya. Hal ini sesuai dengan tuntutan perkembangan ilmu dan teknologi yang semakin maju. Pendidikan merupakan persoalan hidup manusia sepanjang hayatnya, baik sebagai individu, kelompok sosial maupun sebagai bangsa. Sementara itu, pemerintah dan masyarakat berharap agar lulusan dapat menjadi pemimpin, manajer, inovator, operator yang efektif dalam bidang ilmu pengetahuan dan mampu beradaptasi dengan perubahan ilmu dan teknologi saat ini dan memiliki iman dan taqwa yang kuat. Oleh karena itu, beban yang diemban oleh sekolah dalam hal ini guru pendidikan agama Islam sangat berat, karena gurulah yang berada pada garis depan dalam membentuk pribadi anak didik. Dengan demikian sistem pendidikan di masa depan perlu dikembangkan agar dapat menjadi lebih responsif terhadap tuntutan masyarakat dan tantangan yang akan dihadapi di dunia kerja dan di masa mendatang.

Era globalisasi yang ditandai dengan persaingan kualitas menuntut semua pihak dalam berbagai bidang dan sektor pembangunan untuk senantiasa meningkatkan kompetensinya. Hal tersebut mendudukan pentingnya upaya peningkatan kualitas pendidikan baik secara kuantitatif maupun kualitatif yang harus dilakukan terus menerus, sehingga pendidikan dapat digunakan sebagai wahana dalam membangun watak bangsa (Mulyasa, 2007, p. 17).

Pendidikan agama Islam yang diajarkan dan dilaksanakan di sekolah merupakan program pengajaran pada setiap jenjang lembaga pendidikan serta merupakan usaha bimbingan dan pembinaan guru terhadap siswanya untuk memahami, menghayati dan mengamalkan ajaran Islam sehingga menjadi manusia yang bertakwa dan juga menjadi manusia yang berakhlakul karimah. Pendidikan Islam bukan hanya sekedar transfer of knowledge ataupun transfer training, tetapi lebih merupakan suatu sistem yang ditata di atas pondasi keimanan dan kesalehan. Pendidikan Islam berperan membentuk manusia yang berkualitas dan bertakwa kepada Allah SWT Serta menghayati dan mengamalkan ajaran agama Islam dalam kehidupan sehari-hari. 
Pendidikan bagi sebagian besar orang, berarti berusaha membimbing anak untuk menyerupai orang dewasa, sebaliknya Piaget yang dikutip oleh Sagala pendidikan berarti menghasilkan, mencipta, sekalipun tidak banyak sekalipun suatu penciptaan dibatasi oleh pembandingan dengan penciptaan yang lain. Menurut Piaget pendidikan sebagai penghubung dua sisi, sisi individu yang sedang tumbuh dan di sisi lain nilai sosial, intelektual, dan moral yang menjadi tanggung jawab pendidik untuk mendorong individu tersebut. Individu berkembang sejak lahir dan terus berkembang, perkembangan ini bersifat kausal (Sagala, 2013, p. 1).

Secara personal, tinggi kesadaran agama berpengaruh pada teraktualisasinya kesehatan jiwa seseorang dalam kehidupan sehari-hari yang dimanifestasikan dalam bentuk ketenangan jiwa, perasaan aman, dan tenteram. Secara interpersonal, tinggi kesadaran agama akan mengembangkan kemampuan dan keterampilan individu dalam berinteraksi dengan individu lain dan alam sekitarnya (Fathiya, 2007, p. 102).

Pendidikan adalah usaha sadar dan terencana untuk mewujudkan suasana belajar dan proses pembelajaran agar peserta didik secara aktif mengembangkan potensi dirinya untuk memiliki kekuatan spiritual keagamaan, pengendalian diri, kepribadian, kecerdasan, akhlak mulia, serta keterampilan yang diperlukan dirinya, masyarakat, bangsa dan negara, karena pendidikan merupakan tugas dan tanggung jawab bersama antara keluarga, masyarakat dan pemerintah.

Sekolah sebagai lembaga penyelenggara pendidikan yang berinteraksi langsung dengan peserta didik, dituntut untuk terus meningkatkan kualitas pendidikan di lembaga tersebut, sebagai bentuk pengembangan yang terencana, terstruktur dan berkelanjutan (Kasuwi, 2016).

Kualitas pendidikan adalah gambaran dan karakteristik menyeluruh jasa pelayanan pendidikan secara internal, maupun eksternal yang menunjukan kemampunnya, memuaskan kebutuhan yang diharapkan atau yang tersirat mencakup input, proses, dan output pendidikan. Selain itu kualitas pendidikan merupakan kemampuan sistem pendidikan dasar, baik dari segi pengelolaan maupun dari segi proses pendidikan, yang diarahkan secara efektif untuk meningkatkan nilai tambah dan faktor-faktor input agar menghasilkan output yang setinggi-tingginya (Sagala, 2009, p. 170).

Kualitas pendidikan harus diupayakan untuk mencapai kemajuan yang dilandasi oleh suatu perubahan terencana. Menurut Sagala (2009, p. 170) peningkatan kualitas pendidikan diperoleh melalui dua strategi, yaitu: 1) peningkatan kualitas pendidikan yang berorientasi akademis, untuk member dasar minimal dalam perjalanan yang harus ditempuh untuk mencapai kualitas pendidikan yang dipersyaratkan oleh tuntutan zaman, 2) peningkatan kualitas 
yang berorientasi pada keterampilan hidup esensial yang dicukupi oleh pendidikan yang berlandasan luas, nyata dan bermakna.

Sehubungan dengan hal tersebut, ada beberapa indikator pendidikan yang berkualitas, antara lain: 1) Hasil akhir pendidikan merupakan tujuan akhir pendidikan. dari hasil tersebut diharapkan para lulusannya dapat memenuhi tuntutan masyarakat apabila dia bekerja atau melanjutkan studi ke lembaga pendidikan yang lebih tinggi; 2) Hasil langsung pendidikan. Hasil langsung pendidikan yaitu: a) pengetahuan, b) sikap, c) keterampilan. Hasil inilah yang sering digunakan sebagai kriteria keberhasilan pendidikan; 3) Proses pendidikan merupakan interaksi antara raw input, instrumental input, dan lingkungan untuk mencapai tujuan pendidikan; 4) Instrumental input terdiri dari tujuan pendidikan; kurikulum, fasilitas, dan media pendidikan, sistem administrasi pendidikan, guru, sistem penyampaian, evaluasi, serta bimbingan dan penyuluhan; 5) Raw input dan lingkungan juga mempengaruhi kualitas pendidikan. (Nurdin, 2005, p. 79:80)

Saleh (2000, p. 252:254) menyatakan bahwa manajemen peningkatan kualitas pendidikan memiliki karakteristik yang perlu dipahami oleh lembaga pendidikan yang akan menerapkannya, yaitu : karakteristik dari sekolah efektif (effective school), dan manajemen peningkatan kualitas pendidikan yang merupakan wadah atau kerangkanya. Oleh karena itu, karakteristik berikut memuat secara inklusif elemen-elemen sekolah efektif yang dikategorikan menjadi input, proses, dan output. Sedangkan Mantja (2003, p. 33:34) menyatakatakn bahwa manajemen peningkatan kualitas pendidikan mempersyaratkan integrasi dari berbagai faktor, yaitu : pelanggan (klien), kepemimpinan (leadership), tim (team), proses (process), dan struktur (organization).

Fattah (2003, p. 85) menyatakan bahwa pendidikan yang berkualitas harus terlihat dari berbagai komponen, yaitu input, kurikulum, sumber daya manusia, serta penciptaan suasana belajar yang kondusif. Manajemen sekolah yang menjadi otoritas kepala sekolah, dan manajemen kelas yang menjadi otoritas guru berfungsi mensinkronkan berbagai input atau mensinergikan semua komponen dalam proses belajar mengajar.

Sallis menyatakan bahwa manajemen peningkatan kualitas pendidikan merupakan suatu pendekatan yang sistematis, praktis, dan stategis bagi penyelenggaraan pendidikan yang berkualitas dan memuaskan pelangganan. Pendidikan yang berkualitas dan memuaskan pelanggan dapat terwujud apabila dilaksanakan dengan proses yang berkualitas, lebih lanjut Komariah menyatakan terdapat lima pilar untuk mewujudkan pendidikan yang berkualitas yaitu : produk, proses, organisasi, pemimpin, dan komitmen (Komariah, 2008, p. 29:30). 
Dengan melihat masalah kualitas pendidikan yang rupanya sudah sangat menggelitik dunia pendidikan, bukan saja bagi para professional, juga bagi masyarakat luas pun terdapat suatu gerakan yang menginginkan adanya perubahan sekarang juga dalam hal usaha peningkatan kualitas atau mutu pendidikan (Tilaar, 1990, p. 187).

Terdapat beberapa kendala yang biasa dihadapi dalam meningkatan kualitas pendidikan, para ahli memaparkannya sebagai berikut: a) Menurut Soedijarto (2008, p. 56) bahwa rendahnya kualitas atau mutu pendidikan di samping disebabkan oleh karena pemberian peranan yang kurang proporsional terhadap sekolah, kurang memadainya perencanaan, pelaksanaan, dan pengelolaan system kurikulum, dan penggunaan prestasi hasil belajar secara kognitif sebagai satu-satunya indikator keberhasilan pendidikan, juga disebabkan karena sistem evaluasi tidak secara berencana didudukkan sebagai alat pendidikan dan bagian terpadu dari sistem kurikulum; b) Secara umum, Sallis (1984) dalam Total Quality Management in Education menyebutkan, kondisi yang menyebabkan rendahnya mutu pendidikan dapat berasal dari berbagai macam sumber, yaitu miskinnya perancangan kurikulum, ketidak cocokan pengelolaan gedung, lingkungan kerja yang tidak kondusif, ketidaksesuaian sistem dan manajemen, tidak cukupnya jam pelajaran, kurangnya sumber daya, dan pengadaan staf (Syafaruddin, 2002, p. 14).

Gambaran tentang rendahnya kualitas pendidikan sebelumnya telah di dahului oleh serangkaian studi yang dilakukan oleh Proyek Penilaian Nasional Pendidikan (PPNP) yang dimulai sejak tahun 1969. serangkaian studi ini telah memberikan gambaran tentang keadaan pendidikan di Indonesia pada saat itu, dan telah dijadikan landasan bagi dilaksanakan serangkaian pembaruan pendidikan yang dimulai sejak permulaan tahun 1970-an (Soedijarto, 2008, p. 43).

Oleh sebab itu, Menteri Pendidikan Nasional tanggal 2 Mei 2002 telah mencanangkan, bahwa pada tahun 2002 dimulai gerakan peningkatan mutu atau kualitas pendidikan. Gerakan ini perlu diawali dengan mereformasi penyelenggaraan pendidikan di sekolah sebagai lembaga yang memberikan layanan pendidikan apabila menghendaki pendidikan ini bermutu. Gerakan tersebut memang sudah saatnya dimulai, mengingat mutu pendidikan sekarang masih dalam kondisi yang memprihatinkan.

Menurut (Syafaruddin, 2005, p. 290) upaya untuk meningkatkan kualitas atau mutu pendidikan perlu dilakukan hal-hal berikut, yaitu: 1) Menyamakan komitmen mutu atau kualitas oleh kepala sekolah, para guru dan pihak terkait (stakeholders), mencakup: visi, misi, tujuan dan sasaran. 2) Mengusahakan adanya program peningkatan mutu sekolah (kurikulum atau pengajaran, pembinaan siswa, pembinaan guru, keuangan, saran dan prasarana, 
serta kerjasama dengan stakeholders sekolah, meliputi jangka panjang dan jangka pendek. 3) Meningkatkan pelayanan administrasi sekolah. 4) Kepemimpinan kepala sekolah yang efektif. 5) Ada standar mutu lulusan. 6) Jaringan kerjasama yang baik dan luas. 7) Penataan organisasi sekolah atau tata kerja yang baik. 8) Menciptakan iklim dan budaya sekolah yang kondusif.

Peningkatan kualitas pendidikan untuk melatih dan membekali peserta didik dalam pendidikan, bentuk kegiatannya bisa bermacam-macam, salah satunya yaitu dengan kegiatan keagamaan. Harapannya adalah dengan melaksanakan kegiatan keagamaan peserta didik akan dapat melatih dan membiasakan sikap dan tindakan yang ssuai dengan karakter bangsa Indonesia, yaitu: religius, jujur, toleransi, kerja keras, kreatif, demokratis, rasa ingin tahu, mandiri, semangat kebangsaan, cinta tanah air, menghargai prestasi, cinta damai, komunikatif, peduli lingkungan, peduli sosial dan tanggung jawab.

Kenyataan tersebut membuat banyak orang tersadar kembali untuk kemudian semuanya menengok kearah pendidikan, terutama pendidikan agama yang diyakini sebagai instansi yang paling bertanggung jawab terhadap pembentukan moral bangsa, sehingga setiap muncul persoalan dalam kehidupan manusia, maka yang pertama kali dipersalahkan adalah pendidikan. oleh karena itu, pendidikan merupakan investasi sumber daya manusia yang diharapkan mengubah suatu bangsa kearah yang lebih baik.

Sebagai social investment yang berhajat meningkatkan sumber daya manusia. Tentunya pendidikan yang berlangsung di Indonesia tidak semata diharapkan berhasil dalam memindahkan pengetahuan dan nilai-nilai kepada generasi berikutnya, tetapi juga dapat memperbaiki nasib dan kualitas peradaban orang-orangnya (Kurniawan, 2011, p. 5).

Di samping itu, pendidikan merupakan salah satu aspek yang sangat penting untuk membentuk generasi yang siap mengganti tongkat estafet generasi tua dalam rangka membangun masa depan. Karena itu pendidikan berperan mensosialisasikan kemampuan baru kepada mereka agar mampu mengantisipasi tuntutan masyarakat yang dinamis (Muhaimin, 1991, p. 9).

Pendidikan merupakan bagian integral dalam kehidupan bangsa dan negara. Salah satu faktor yang dilakukan untuk meningkatkan kualitas hidup bangsa Indonesia dengan meningkatkan kualitas pendidikan. Hal tersebut menunjukan bahwa kualitas pendidikan sangat menentukan kualitas sistem pendidikan secara menyeluruh, terutama berkaitan dengan kualitas pendidikan serta relevansinya dengan kebutuhan masyarakat dan dunia kerja (RI, 2010, p. $1)$.

Sekolah berupaya mengadakan peningkatan kualitas pendidikan dengan kegiatan keagamaan yang berkaitan dengan pendidikan agama Islam yakni untuk membentuk karakter dan tumbuhnya motivasi yang kuat untuk 
melakukan pembelajaran karena tanpa adanya peningkatan kualitas pendidkan maka akan lemah pula untuk melakukan pembelajaran pendidikan agama Islam dan pelajaran lainnya, di dalam kegiatan ini sangatlah banyak pengaruhnya baik dari meningkatnya motivasi belajar, memperkuat keimanan, menumbuhkan rasa kemanusiaan dan menanamkan jiwa sosialisasi terhadap siswa. Salah satunya sebagaimana dalam al-Qur'an surat al-Qashash ayat 77, sebagai berikut:

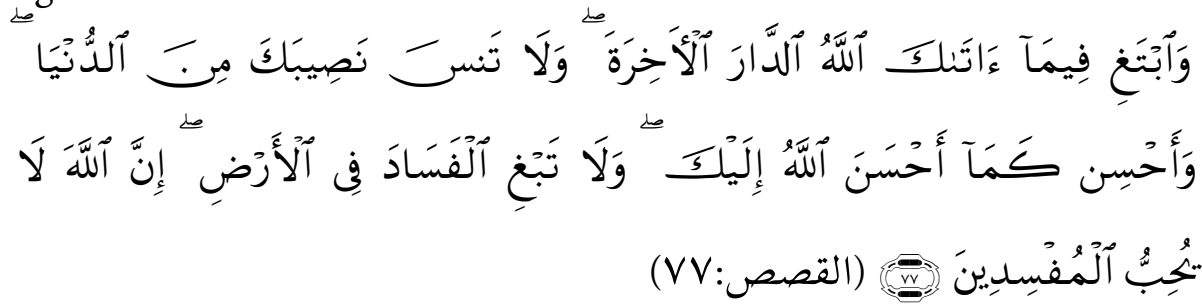

Dan carilah pada apa yang telah dianugerahkan Allah kepadamu (kebahagiaan) negeri akhirat, dan janganlah kamu melupakan bahagianmu dari (kenikmatan) duniawi dan berbuat baiklah (kepada orang lain) sebagaimana Allah telah berbuat baik, kepadamu, dan janganlah kamu berbuat kerusakan di (muka) bumi. Sesungguhnya Allah tidak menyukai orang-orang yang berbuat kerusakan (Q.S. Al-Qashash, 28 : 77).

Kegiatan keagamaan dalam pendidikan agama dimanapun harus mencakup semua aspek. Pelaksanaan pendidikan agama mampu menghantarkan peserta didik kepada setidaknya tiga aspek. Pertama, aspek keimanan, mencakup seluruh arkanul iman. Kedua, aspek ibadah, mencakup arkanul islam. Ketiga, aspek akhlak, mencakup seluruh akhlakul karimah. Kegiatan keagamaan bermaksud untuk penanaman jiwa atau sikap keagamaannya pada peserta didik bukan pengajaran agama (Daulay, 2004, p. 38).

Kegiatan keagaman terdiri dari dua kata yaitu kegiatan dan keagamaan. Kegiatan mempunyai arti kesibukan atau aktivitas. Secara lebih luas kegiatan atau aktivitas dapat diartikan sebagai perbuatan atau kegiatan yang dilakukan oleh seseorang dalam kehidupan sehari-hari berupa ucapan, perbuatan ataupun kreatifitas ditengah lingkungan. Sedangkan keagamaan adalah sifat-sifat yang terdapat dalam agama atau segala sesuatu mengenai agama (Poerwodarminto, 1997, p. 20).

Kegiatan keagamaan adalah segala bentuk aktifitas yang dilakukan seseorang yang berhubungan dengan agama. Dalam upaya mengembangkan kegiatan keagamaan, seorang guru yang kreatif selalu berupaya mencari cara agar agenda kegiatan yang direncanakan dapat berhasil sesuai dengan harapkan (Nyimas, 2017). Keagamaan adalah sifat yang terdapat dalam agama, segala sesuatu mengenai agama, untuk itu latihan keagamaan adalah merupakan sikap yang tumbuh atau dimiliki seseorang dan dengan sendirinya akan mewarnai 
sikap dan tindakan dalam kehidupan sehari-hari. Bentuk sikap dan tindakan yang dimaksdukan yakni yang sesuai dengan ajaran agama, dari pengertian di atas kegiatan keagamaan adalah usaha yang dilakukan seseorang atau perkelompok yang dilaksanakan secara terus-menerus maupun yang ada hubungannya dengan nilai-nilai keagamaan. Dikarenakan dalam hal ini adalah yang berhubungan dengan agama Islam maka kegiatan-kegiatan keagamaan disini yang ada korelasinya dengan pelaksanaan nilai-nilai agama Islam itu sendiri misalnya, dizikir, ceramah atau tausiah keagamaan, membaca asmaul husna bersama (Usman, 2010, p. 22).

Segala sesuatu yang dilaksanakan, tentu mempunyai tujuan dan fungsi yang hendak dicapai. Pada dasarnya kegiatan keagamaan merupakan usaha yang dilakukan terhadap peserta didik agar dapat memahami, mengamalkan ajaran-ajaran agama. Sehingga tujuan dan fungsi dari kegiatan keagamaan secara umum tidak terlepas dari tujuan dan fungsi pendidikan Islam dan pendidikan agama Islam. Pendidikan Islam adalah universal dan hendaknya diarahkan untuk menyadarkan manusia bahwa diri mereka adalah hamba Tuhan yang berfungsi menghambakan diri kepada-Nya (Sasono, 1998, p. 87).

Menurut (Zuhairini, 1998, p. 45) bahwa tujuan pendidikan agama Islam adalah membina anak agar menjadi orang muslim sejati, beriman tegas dan berakhlak mulia serta berguna bagi masyarakat, agama dan bangsa. Sedangkan Menurut Ibn Khaldun sebagaimana dikutip oleh (Ramayulis, 1994, p. 25) bahwa tujuan pendidikan Islam mempunyai dua tujuan yaitu: a) Tujuan keagamaan, maksudnya adalah beramal untuk akhirat, sehingga ia menemui Tuhannya dan telah menunaikan hak-hak Allah yang diwajibkan kepadanya; b) Tujuan ilmiah yang bersifat keduniaan, yaitu yang diungkapkan oleh pendidikan modern dengan tujuan kemanfaatan atau persiapan untuk hidup.

Secara ideal pendidikan Islam berfungsi menyediakan sumber daya manusia yang berkualitas tinggi, baik penguasaan terhadap ilmu pengetahuan, teknologi dan maupun dalam hal sikap moral, dan penghayatan serta pengamalan ajaran agama Islam. Sedikitnya pendidikan Islam secara ideal berfungsi membimbing, menyulap anak didik yang berilmu, berteknologi, berketerampilan tinggi dan sekaligus beriman dan beramal sholeh (Azra, 2003, p. 57).

Sebagai suatu mata pelajaran, pendidikan agama Islam mempunyai fungsi yang berbeda dari pelajaran yang lain, pendidikan agama Islam di sekolah memiliki fungsi sebagai berikut: a) Pengembangan, yaitu meningkatkan keimanan dan ketaqwaan peserta didik kepada Allah SWT yang telah ditanamkan dalam lingkungn keluarga. Sekolah berfungsi menumbuhkembangkan lebih lanjut dalam diri anak melalui bimbingan, pengajaran, pelatihan, agar keimanan dan ketaqwaan tersebut dapat 
berkembang secara optimal sesuai dengan tingkat perkembangannya; b) Penanaman nilai sebagai pedoman hidup untuk mencari kebahagiaan di dunia dan di akhirat; c) Penyesuaian mental, yaitu untuk menyesuaikan diri dengan lingkungannya, baik lingkungan fisik maupun lingkungan sosial dan dapat mengubah lingkungannya sesuai dengan ajaran agama Islam; d) Perbaikan, yaitu untuk memperbaiki kesalahan-kesalahan, kekurangan-kekurangan, dan kelemahan-kelemahan peserta didik dalam keyakinan, pemahaman, dan pengalaman ajaran dalam kehidupan sehari-hari; e) Pencegahan, yaitu untuk mengungkapkan hal-hal negatif dari lingkungannya atau dari budaya lain yang dapat membahayakan dirinya dan menghambat perkembangannya menuju manusia Indonesia seutuhnya; f) Pengajaran tentang ilmu pengetahuan keagamaan secara umum, sistem dan fungsionalnya; g) Penyaluran, yaitu untuk menyalurkan peserta didik yang memiliki bakat khusus di bidang agama Islam agar bakat tersebut dapat berkembang secara optimal sehingga dapat dimanfaatkan untuk dirinya sendiri dan bagi orang lain (Wiyani, 2012, p. 92:93).

Kegiatan keagamaan adalah kegiatan yang bertujuan untuk memberikan pemahaman, penghayatan, pengalaman tentang ajaran agama Islam guna pembinaan keimanan, ketakwaan dan akhlakul karimah.

Dalam buku Petunjuk Pelaksanaan Pendidikan Agama Islam disebutkan contoh kegiatan keagamaan adalah sebagai berikut : 1) Musabaqoh Tilawatil Quran, 2) Ceramah pengajian mingguan, 3) Peringatan Hari Besar, 4) Kunjungan ke museum, ziarah ke makam Islam, 5) Seni Kaligrafi, 6) Penyelenggaraan shalat jumat, shalat tarawih, 7) Cinta alam (Saleh, 2000, p. 169).

Peningkatan kualitas pendidikan bukanlah tugas yang ringan karena tidak hanya berkaitan dengan permasalahan teknis, tetapi mencakup berbagai persoalan yang sangat rumit dan kompleks, baik yang menyangkut masalah perencanaan, pendanaan, maupun efisiensi dan efektifitas penyelenggaraan sistem sekolah (Mulyasa, 2007, p. 21).

Sekolah sebagai lembaga pendidikan terikat dengan norma dan budaya yang mendukungnya sebagai sebuah nilai. Postman and Weingartner mengemukakan "School as institution is the specific set of essential function is server in our society". Sekolah didefinisikan sebagai institusi yang spesifik dari seperangkat fungsi-fungsi yang mendasar dalam melayani masyarakat (Sagala, 2004, p. 53).

Salah satu sekolah yang menerapkan kegiatan keagamaan di sekolah Madrasah Tsanawiyah Negeri 4 Pangandaran, Sekolah tersebut sudah cukup baik di dalam melaksanakan kegiatan yang berkaitan dengan keislaman dan membantu untuk menumbuhkan motivasi belajar yang kuat untuk siswa dan 
siswinya, kenapa dikatakan sudah cukup baik dalam melaksanakan kegiatan keagamaan tersebut karena di sekolah Madrasah Tsanawiyah Negeri 4 Pangandaran di dalam melaksanakan kegiatan tersebut dengan terstruktural mulai dari petugas yang memimpin diberikan kepada siswa guna melatih mental dan pengetahuan siswa di dalam bidang keagamaan selain itu juga siswa aktif dan sangat berpartisipasi di dalam kegiatan keagamaan yang dilakukan di sekolah tersebut.

Dari latar belakang diatas penulis tertarik untuk melakukan penelitian dengan mengambil judul "Pengaruh Kegiatan Keagamaan Terhadap Kualitas Pendidikan (Penelitian Madrasah Tsanawiyah Negeri 4 Pangandaran)”.

Hipotesis dalam penelitian ini adalah: $\mathrm{H}_{\mathrm{a}}$ : Terdapat hubungan positif yang signifikan antara Kegiatan Keagamaan terhadap Kualitas Pendidikan di Madrasah Tsanawiyah Negeri 4 Pangandaran. $\mathrm{H}_{\mathrm{o}}$ :Tidak terdapat hubungan positif yang signifikan antara Kegiatan Keagamaan terhadap Kualitas Pendidikan di Madrasah Tsanawiyah Negeri 4 Pangandaran.

Oleh sebab itu untuk menguji hipotesis tersebut akan dilakukan sebuah penelitian yang berjudul "Pengaruh Kegiatan Keagamaan Terhadap Kualitas Pendidikan (Penelitian di Madrasah Tsanawiyah Negeri 4 Pangandaran)".

\section{Metode Penelitian}

Jenis penelitian ini adalah penelitian kuantitatif. Penelitian kuantitatif merupakan suatu proses menemukan pengetahuan yang menggunakan data berupa angka sebagai alat menemukan keterangan mengenai apa yang ingin kita ketahui (Margono, 2004, p. 105).

Penelitian kuantitatif adalah penelitian yang analisisnya lebih fokus pada data-data numerikal (angka) yang diolah dengan menggunakan metode statistik. Pada umumnya penelitian menggunakan penelitian kuantitatif merupakan penelitian sampel besar, karena pada penelitian kuantitatif dilakukan pada penelitian inferensial yaitu dalam rangka pengujian hipotesis dan menyadarkan kesimpulan pada suatu probabilitas kesalahan penolakan hipotesis nihil. Dengan menggunakan penelitian ini, maka akan diperoleh signifikasi hubungan antar variabel yang diteliti.

Metode penelitian yang digunakan oleh peneliti adalah metode penelitian lapangan korelasional (correlational research) yaitu untuk menyelidiki sejauh mana variasi-variasi pada suatu faktor berkaitan dengan variasi-variasi pada satu atau lebih faktor lain berdasarkan koefisien korelasi. Pengertian "penelitian korelasi disebut penelitian hubungan atau asosiatif. Penelitian korelasi adalah penelitian untuk mengetahui dua variabel atau lebih dengan mengukur koefisien atau signifikansi dengan menggunakan statistik" 
(Musfiqon, 2012, p. 63).

Tempat Penelitian dilaksanakan di Madrasah Tsanawiyah Negeri 4 Pangandaran yang terletak di Jalan Mangunjaya No. 125 Hegarmanah Desa Sindangjaya Kecamatan Mangunjaya Kabupaten Pangandaran dengan pertimbangan tempat tersebut merupakan tempaat domisili peneliti, sehingga mempermudah untuk mendapatkan data-data yang diperlukan. Penelitian ini dilaksanakan dalam jangka waktu kurang lebih lima bulan, yaitu dari mulai bulan Agustus sampai dengan bulan Desember 2018.

Populasi adalah keseluruhan objek penelitian yang terdiri dari manusia, benda-benda, hewan, tumbuhan-tumbuhan, gejala-gejala, nilai tes atau peristiwa sebagai sumber data yang memiliki karakteristik tertentu di dalam suatu penelitian (Margono, 2004, p. 118).

Dapat dipahami, populasi adalah kelompok besar individu yang mempunyai karakteristik tertentu atau keseluruhan subjek peneliitian. Adapun yang menjadi populasi dalam penelitian ini seluruh siswa di Madrasah Tsanawiyah Negeri 4 Pangandaran yang berjumlah 340 siswa, terbagi menjadi sepuluh kelas.

Sampel yaitu sebagian dari seluruh individu yang menjadi obyek penelitian (Arikunto, 2006, p. 118). Teknik sampling yang akan peneliti gunakan adalah probability sampling maksudnya adalah teknik yang memberikan kesempatan yang sama bagi setiap unsur atau anggota populasi untuk dipilih menjadi sampel.

Selanjutnya untuk penentuan sampel peneliti menggunakan teknik sistematik random sampling dengan tujuan agar populasi yang mendapat kesempatan untuk dijadikan sampel. Penulis pada pengambilan sampel yang dilakukan berpedoman pada pendapat Arikunto (2006, p. 120) yang menyatakan bahwa "Apabila subjeknya kurang dari 100, lebih baik diambil semuanya sehingga penelitiannya merupakan penelitian populasi. Jika subyeknya lebih dari 100 dapat diambil antara 10\% - 15\% atau 20\% - 25\%".

Dengan memperhatikan di atas, maka penulis mengambil $10 \%$ dari jumlah populasi yang ada, dan perhitungannnya adalah $340 \times 10 \%=34$. Jadi sampel yang diambil adalah 34siswa dari jumlah populasi 340 siswa. Penulis menyebarkan angket kepada 34 siswa untuk mengolah data. Dengan demikian sampel yang diambil dalam penelitian ini adalah 34 responden.

Istilah variabel merupakan istilah yang tidak pernah ketinggalan dalam setiap jenis penelitian. Sutrisno Hadi mendefinisikan variabel sebagai gejala yang bervariasi karena gejala adalah objek penelitian, sehingga variabel adalah objek penelitian yang bervariasi. Dalam penelitian ini mencakup dua variabel yaitu pengaruh kegiatan keagamaan terhadap kualitas pendidikan (Arikunto, 2006, p. 94). Variabel X adalah kegiatan keagamaan yaitu sebagai variabel 
bebas (variabel independen). Variabel $\mathrm{Y}$ adalah kualitas pendidikan yaitu sebagai variabel terikat (variabel dependen).

Dalam pengumpulan data peneliti menggunakan teknik-teknik sebagai berikut: a) Observasi. Observasi adalah pengamatan dan pencatatan yang sistematis terhadap gejala-gejala yang diteliti. Observasi adalah teknik yang digunakan oleh peneliti untuk mengetahui aktivitas-aktivitas yang terjadi selama penelitian dengan mengamati secara langsung (Sugiyono, 2014, p. 203). Dalam penelitian ini observasi digunakan untuk memperoleh data atau informasi tentang kegiatan keagamaan, kualitas pendidikan dan pendukung lainnya di Madrasah Tsanawiyah Negeri 4 Pangandaran; b) Angket. Angket adalah suatu alat pengumpul informasi dengan cara menyampaikan sejumlah pertanyaan tertulis untuk dijawab secara tertulis pula oleh reponden (Margono, 2004, p. 167). Dalam penelitian ini digunakan untuk mendapat data dan informasi dari responden tentang kegiatan keagamaan (variabel $\mathrm{X}$ ) dengan kualitas pendidikan (variabel Y). Angket disebarkan kepada siswa Madrasah Tsanawiyah Negeri 4 Pangandaran, dengan jumlah 40 item pernyataan yaitu 20 item tentang kegiatan keagamaan dan 20 item tentang kualitas pendidikan; c) Dokumentasi. Dokumentasi adalah mencari data mengenai hal-hal atau variabel yang berupa catatan, transkip, buku, surat kabar, majalah, prasasti, notulen, rapat, agenda dan sebagainnya (Arikunto, 2006, p. 206). Bentuk dokumentasi yang peneliti gunakan yaitu pengarsipan dari data-data di Madrasah Tsanawiyah Negeri 4 Pangandaran yang diperlukan melaui data kepegawain, data kesiswaan, daftar nilai laport, profil sekolah, dan hasil angket yang telah disebarkan mengenai kegiatan keagamaan dan kualitas pendidikan.

Dalam menganalisis data yang telah terkumpul, penulis menggunakan metode statistik, karena jenis penelitian yang digunakan adalah penelitian kuantitatif. Tujuan analisis ini adalah menyederhanakan data dalam bentuk yang lebih mudah dibaca dan ditafsirkan. Analisis statistik deskriptif adalah analisis yang digunakan untuk menganalisis data dengan cara mendeskripsikan atau menggambarkan yang telah terkumpul sebagaimana adanya tanpa bermaksud membuat kesimpulan yang berlaku umum atau generalisasi (Sugiyono, 2014, p. 148).

Analisis ini meliputi editing data, penskoran penyajian data dengan tabel, perhitungan modus, mean dan median.

Editing data adalah kegiatan yang dilaksanakan setelah peneliti selesai menghimpun data dilapangan. Pada tahap ini peneliti akan melakukan pengecekan terhadap data yang diperoleh, khususnya pada angket yang telah diisi oleh siswa. Angket tersebut diteliti satu persatu tentang kelengkapan pengisian, kejelasan penelitiannya dan kebenaran pengisian angket, sehingga terhindar dari kekeliruan dan kesalahan. 
Tahap selanjutnya setelah dilakukan pengecekan angket kemudian pemberian skor pada setiap butir-butir pertanyaan yang terdapat dalam angket. Pemberian skor ini dilakukan dengan memperhatikan jenis data yang ada.

Analisis statistik inferensial digunakan untuk menguji hipotesis penelitian dengan menggunakan t-test. Namun, sebelum dilakukan menguji hipotesis terlebih dahulu dilakukan prasyarat yang terdiri dari uji normalitas dan uji linearitas.

Dalam uji prasyarat ada dua yakni uji normalitas dan uji linearitas. Di mana penelitian ini dihitung dengan program SPSS versi 20. Dalan uji hipotesis menggunakan manual dan SPPS versi 20, di mana uji yang dilakukan dengan uji korelasi, uji regresi linear sederhana, uji t (uji parsial) dan uji koefisien determinasi.

\section{Hasil Penelitian dan Pembahasan}

Pada tahun ajaran 2018/2019, keadaan siswa Madrasah Tsanawiyah Negeri 4 Pangandaran sebanyak 340 orang siswa dari tiga angkatan kelas VII-IX yang dibagi menjadi 12 rombel.

Data dalam penelitian terdiri ini atas dua variabel, yaitu kegiatan keagamaan sebagai variabel 1 (variabel $\mathrm{X}$ ) dan kualitas pendidikan sebagai variabel 2 (variabel $\mathrm{Y}$ ).

Untuk mengetahui data tentang kegiatan keagamaan peneliti memberikan kuesioner kepada 34 orang responden. Setiap kuesioner berisi 20 pernyataan yang harus ditanggapi oleh masing-masing responden (siswa-siswi Madrasah Tsanawiyah Negeri 4 Pangandaran). Dapat diketahui bahwa skor mean 80,38, median sebesar 80,00, modus sebesar 80,00, standar deviasi 3,62, skor minimum 70,00 dan skor maksimumnya sebesar 88,00 . Berikut ini adalah dari tabel prosentase dari variabel X (kegiatan keagaman).

Untuk mengetahui data tentang kualitas pendidikan, peneliti memberikan kuesioner kepada 34 orang responden. Setiap kuesioner berisi 20 pernyataan yang harus ditanggapi oleh masing-masing responden (siswa-siswi Madrasah Tsanawiyah Negeri 4 Pangandaran). Dan dapat diketahui bahwa skor mean 82,05, median sebesar 82,00, modus sebesar 83,00, standar deviasi 2,43, skor minimum 75,00 dan skor maksimumnya sebesar 89,00. Berikut ini adalah tabel prosentase dari variabel Y (kualitas pendidikan).

Pengujian normalitas menggunakan kolmogorov-smirnov hal ini dilakukan untuk mengetahui normal tidaknya suatu distribusi data. Data dikatakan berdistribusi normal jika skor $s i g>0,05$. Hasil uji normalitas kolmogorov-smirnov dengan bantuan SPSS 20 di atas diperoleh bahwa kegiatan 
keagamaan diperoleh skor sig sebesar $0.537>$ dari 0,05, maka dapat disimpulkan bahwa data tersebut berdistribusi normal.

\section{Uji Linearitas}

Pengujian linearitas menggunakan output "Tabel Anova" hal ini dilakukan untuk mengetahui linear tidaknya suatu distribusi data. Data dikatakan berdistribusi normal jika sig $<0,05$. Hasil uji linearitas diperoleh skor sig sebesar $0.000<$ dari 0,05 , maka dapat disimpulkan bahwa antara variabel kegiatan keagamaan dan kualitas pendidikan terdapat hubungan linear secara signifikan.

Regresi Linear Sederhana

Pada tabel model summary, diperoleh hasil $\mathrm{R}$ square sebesar 0,662 angka ini adalah hasil dari penguadratan dari harga koefisien korelasi yaitu 0,814 x 0,814 . $R$ square disebut juga koefisien determinasi, yang berarti $66 \%$ variabel kualitas pendidikan dipengaruhi oleh variabel kegiatan keagamaan. $\mathrm{R}$ square berkisar dalam rentang $0-1$, semakin besar harga $\mathrm{R}$ square maka semakin kuat hubungan kedua variabel.

Penelitian ini bertujuan untuk menguji antara kegiatan keagamaan dengan kualitas pendidikan di Madrasah Tsanawiyah Negeri 4 Pangandaran. Berdasarkan hasil analisis regresi linear sederhana yang menunjukan bahwa adanya pengaruh atau hubungan antara kegiatan keagamaan dan kualitas pendidikan di Madrasah Tsanawiyah Negeri 4 Pangandaran.

Hasil analisis deskriptif diperoleh gambaran secara umum mengenai kegiatan keagamaan menunjukan bahwa nilai rerata (mean) yang diperoleh siswa 80,38. Adapun hasil kualitas pendidikan menunjukan bahwa nilai rerata (mean) yang diperoleh siswa 82,05. Dari hasil perolehan rerata (mean), terlihat terdapat perbedaan antara kegiatan keagamaan dan kualitas pendidikan dengan adanya kenaikan rerata (mean), kegiatan keagamaan yaitu 80,38 dan kualitas pendidikan yaitu 82,05.

Hasil analisis statistik inferensial di tunjukkan dari hasil analisis regresi linear sederhana sebesar $\mathrm{r}$ hitung 0,814 dibandingkan dengan $\mathrm{r}$ tabel tingkat signifikan $5 \% \mathrm{~N}=34$ sebesar 0,547 . Jadi $\mathrm{r}_{\text {hitung }} 0,814>\mathrm{r}_{\text {tabel }} 0,547$ maka dapat ditarik bahwa $\mathrm{H}_{\mathrm{o}}$ ditolak dan $\mathrm{H}_{\mathrm{a}}$ diterima. Dengan koefisien determinasi sebesar 66,3\% (dibulatkan menjadi 66\%) maka berpengaruh positif, artinya kegiatan keagamaan mampu memberikan pengaruh terhadap kualitas pendidikan menjadi lebih baik. Sedangkan 34\% merupakan faktor yang mempengaruhi variabel $\mathrm{Y}$ dari faktor yang tidak diteliti oleh peneliti. 


\section{Kesimpulan}

Berdasarkan analisis skor nilai angket siswa menunjukan bahwa rerara (mean) dengan nilai 80,38 dari variabel $\mathrm{X}$ tentang kegiatan keagamaan tergolong sedang karena termasuk dalam interval (77-79) artinya pengaruh kegiatan keagamaan termasuk pada tingkat kualifikasi cukup untuk mempengaruhi kualitas pendidikan di Madrasah Tsanawiyah Negeri 4 Pangandaran. Berdasarkan analisis skor nilai angket siswa menunjukan bahwa rerata (mean) dengan nilai 82,05 dari variabel $Y$ tentang kualitas pendidikan tergolong cukup karena termasuk dalam interval (81-83) artinya kualitas pendidikan termasuk pada tingkat kualifikasi baik. Dengan demikian, dilihat dari kegiatan keagamaan tidak menutup kemungkinan kualitas pendidikan di Madrasah Tsanawiyah Negeri 4 Pangandaran adalah sangat baik. Terdapat pengaruh yang signifikan antara kegiatan keagamaan dan kualitas pendidikan. Hal ini diperoleh dari analisis SPSS 20. Dari nilai analisis tersebut diketahui bahwa nilai $r=0,814$ dan $r^{2}=0,662$. Kemudian nilai $\mathrm{t}_{\text {hitung }}>\mathrm{t}_{\text {tabel }}$ yakni 7,916 $>1.693$ pada taraf signifikasi $5 \%$ yang berarti korelasi antara variabel $\mathrm{X}$ dan variabel $\mathrm{Y}$ itu ada terdapat korelasi yang cukup kuat, maka $\mathrm{H}_{\mathrm{o}}$ ditolak dan $\mathrm{H}_{\mathrm{a}}$ diterima. Jadi, dapat disimpulkan bahwa kegiatan keagamaan berpengaruh terhadap kualitas pendidikan. Dilihat kembali dari uji determinasi (R2) mendapatkan nilai sebesar 66,3 atau 66\%. Hal ini menunjukan bahwa kegiatan keagamaan berpengaruh tinggi atau kuat terhadap kualitas pendidikan.

\section{DAFTAR PUSTAKA}

Arikunto, S. (2006). Prosedur Penelitian Suatu Pendekatan Praktek. Jakarta: Rineka Cipta.

Azra, A. (2003). Pendidikan Islam Tradisional dan Modernis Menuju Melenium Baru. Jakarta: Depdiknas.

Daulay, H. P. (2004). Pendidikan Islam Dalam Sistem Pendidikan Nasional di Indonesia. Jakarta: Prenada Media Group.

Fathiya, A. (2007). Analisis Teori Belajar Orang Dewasa dan Penerapannya dalam Pengembangan Kemandirian Pengadaan Energi Alternatif pada Masyarakat Nelayan. Buletin Ekonomi Perikanan IPB, VII(5).

Fattah, N. (2003). Landasan Manajemen Pendidikan. Bandung: Remaja Rosydakarya.

Kasuwi. (2016). Upaya Peningkatan Kualitas Pendidikan Agama di Perguruan Tinggi Umum. Jurnal Ilmu Pendidikan, 13(2), 69-74. Retrieved from http://garuda.ristekdikti.go.id/journal/article/3244 
Komariah, A. (2008). Visionary Leadership Menuju Sekolah Efektif. Jakarta: Bumi Aksara.

Kurniawan, S. (2011). Jejak Pemikiran Tokoh Pendidikan Islam. Yogyakarta: Ar-Ruzz Media.

Mantja, W. (2003). Etnografi Desain Penelitian Kualitatif dan Manajemen Pendidikan. Malang: Winaka Media.

Margono, S. (2004). Metodologi Penelitian Pendidikan. Jakarta: Rineka Cipta.

Muhaimin. (1991). Konsep Pendidikan Islam. Solo: Ramadlan.

Mulyasa, E. (2007). Manajemen Berbasis Sekolah,. Bandung: Remaja Rosydakarya.

Musfiqon, H. (2012). Panduan lengkap metodologi penelitian pendidikan. Jakarta: Prestasi Pustaka Raya.

Nurdin, M. (2005). Pendidikan yang Menyebalkan. Yogyakarta: Ar-Ruzz Media.

Nyimas, N. (2017). Strategi Pengembangan Kegiatan Keagamaan Anak Usia Dini di TK Harapan Ibu Tanah Mas Banyuasin. El-Ghiroh, XIII(2).

Poerwodarminto, W. J. S. (1997). Kamus Umum Bahasa Indonesia. Jakarta: Balai Pustaka.

Ramayulis. (1994). Ilmu Pendidikan Islam. Jakarta: Kalam Mulia.

Sagala, S. (2004). Manajemen Berbasis Sekolah dan Masyarakat. Jakarta: Nimas Multina.

Sagala, S. (2009). Manajemen Strategik dalam Peningkatan Mutu Pendidikan. Bandung: Alfabeta.

Sagala, S. (2013). Konsep dan Makna Pembelajaran, Bandung: Alfabeta. Bandung: Alfabeta.

Saleh, A. R. (2000). Pendidikan Agama dan Keagamaan. Jakarta: PT. Gemawindu Pancaperkasa.

Sasono, A. (1998). Solusi Islam Atas Problematika Umat. Jakarta: Gema Insani Press.

Soedijarto. (2008). Landasan dan Arah Pendidikian Nasional Kita. Jakarta: Kompas Media Nusantara.

Sugiyono. (2014). Metode Penelitian Kuantitatif Kualitatif dan $R$ \& $D$. Bandung: Alfabeta.

Syafaruddin. (2002). Manajemen Mutu Terpadu dalam Pendidikan Konsep, Strategi, dan Aplikasi. Jakarta: PT Gramedia Widiasarana Indonesia.

Syafaruddin. (2005). Manajemen Lembaga Pendidikan Islam. Jakarta: Ciputat Press.

Tilaar, H. A. R. (1990). Pendidikan Dalam Pembangunan Nasional Menyongsong Abad XXI. Jakarta: Balai Pustaka.

Usman, U. (2010). Menjadi Guru Profesional. Bandung: Remaja Rosydakarya. 
Wiyani, N. A. (2012). Pendidikan Karakter Berbasis Iman dan Taqwa. Yogyakarta: Teras.

Zuhairini. (1998). Metodik Khusus Pendidikan Agama. Malang: Sunan Ampel. 
